\title{
PROSES DAN PENGEMBANGAN PENDIDIKAN ISLAM
}

\author{
Fatkhul Mubin \\ fatkhulmubin90@gmail.com
}

PENDAHULUAN

\section{A. Latar Belakang}

Tujuan umum pendidikan adalah persiapan atas tugas pelayanan publik. Secara psikologi, tujuhan pendidikan adalah pembentukan karakter yang berwujud dalam kesatuan esensial si subyek dengan perilaku dan sikap hidup yang dimilikinya. Para pakar pendidikan sepakat mengatakan "perlunya keseimbangan antara demensi kognitif dan efektif dalam proses pendidikan". untuk membentuk manusia seutuhannya tidak cukup hanya dengan mengembangkan kecerdasan berpikir atau IQ anak didik melaluhi segudangan ilmu pengetahuan, melainkan juga harus dibarengin dengan pengembangan perilaku dan kesadaran moral. karena dengan hanya kombinasi seperti itulah pserta didik akan mampuh mengargai nilai-nilai yang ada di dalam dirinya dan orang lain. ${ }^{1}$

Pendidikan Agama Islam yang selama ini berlangsung agaknya terasa kurang terkait atau kurang concern terhadap persoalan bagaimana mengubah pengetahuan agama yang bersifat kognitif menjadi makna dan nilai yang perlu diinternasionalisasikan dalam diri peserta didik untuk bergerak, berbuat dan berperilaku secara kongkret-agamis dalam kehidupan praksis sehari-hari. ${ }^{2}$ Pelaksanaan pendidikan agama yang berlangsung di sekolah bisa dikatakan masih mengalami banyak kelemahan, bahkan bisa dikatakan masih gagal. Kegagalan ini disebabkan karena praktik pendidikannya hanya memerhatikan aspek kognitif semata dari pertumbuhan kesadaran nilai-nilai (agama), dan mengabaikan pembinaan aspek afektif dan konatif-volitif, yakni kemauan dan tekad mengamalkan nilai-nilai ajaran agama. Akibatnya terjadi kesenjangan antara pengetahuan dan pengalaman, antara gnosis dan praxis dalam kehidupan nilai agama. Atau dalam praktik pendidikan agama berubah menjadi pengajaran agama, sehingga tidak mampu membentuk pribadi-pribadi bermoral, padahal intisari dari pendidikan agama adalah pendidikan moral. $^{3}$

\section{B. Rumusan Masalah}

1 Saihu, S. (2019). RINTISAN PERADABAN PROFETIK UMAT MANUSIA MELALUI PERISTIWA TURUNNYA ADAM AS KE-DUNIA. Mumtaz: Jurnal Studi Al-Quran dan Keislaman, 3(2), 268-279,

Saihu, S. (2019). Pendidikan Pluralisme Agama: Kajian tentang Integrasi Budaya dan Agama dalam Menyelesaikan Konflik Sosial Kontemporer. Jurnal Indo-Islamika, 9(1), 67-90,

Saihu, S. (2019). IMPLEMENTASI MANAJEMEN BALANCED SCORECARD DI PONDOK PESANTREN JAM'IYYAH ISLAMIYYAH TANGERANG SELATAN. Mumtaz: Jurnal Studi Al-Quran dan Keislaman, 3(1), 1-22.

Saihu, S. (2019). KOMUNIKASI PENDIDIK TERHADAP ANAK BERKEBUTUHAN KHUSUS DI SEKOLAH KHUSUS ASY-SYIFA LARANGAN. Andragogi: Jurnal Pendidikan Islam dan Manajemen Pendidikan Islam, 1(3), 418-440.

Saihu, S., \& Marsiti, M. (2019). PENDIDIKAN KARAKTER DALAM UPAYA MENANGKAL RADIKALISME DI SMA NEGERI 3 KOTA DEPOK, JAWA BARAT. Andragogi: Jurnal Pendidikan Islam dan Manajemen Pendidikan Islam, 1(1), 23-54.

2 Muhaimin, Paradigma Pendidikan Islam,Upaya Mengefektifkan Pendidikan Agama Islam di Sekolah (Bandung: Remaja Rosdakarya, 2004), hlm. 168.

${ }^{3}$ Muhaimin, Pengembangan Kurikulum Pendidikan Agama Islam di Sekolah, Madrasah, dan Perguruan Tinggi (Jakarta: RajaGrafindo Persada, 2009), hlm. 23. 
Berdasarkan latar belakang yang telah dijelaskan maka penulis dapat merumuskan beberapa permasalahan yang ingin dipaparkan dalam makala ini terkait dengan proses dan pengembangan pendidikan islam. Adapun rumusan masalah yang akan dipaparkan dalam bentuk sebegai beriku:

1. Bagaimana membetuk proses pendidikan yang lebih kuat

2. Bagaimana proses dan pengembangan pendidikan islam

3. Bagaimana tujuan pendidikan islam

C. Tujuhan

Adapun tujuan dari pembahasan makala ini adalah sebagai berikut:

1. Untuk memahami proses dan pengembangan pendidikan

2. Untuk mengetahui tujuan pendidikan

3. Untuk memahami bentuk proses pendidikan

\section{A. Proses pendidikan}

\section{BAB II \\ PEMBAHASAN}

Proses pendidikan merupakan kegiatan memobilisasi segenap komponen pendidikan oleh pendidikan terarah kepada pencapaian tujuhan pendidikan. bagaimana proses pendidikan itu dilaksanakan sangat menentukan kualitas hasil pencapaian tujuhan pendidikan. Kualitas proses pendidikan menggejala pada dua sigi, yaitu kualitas komponennya cukup baik, seperti tersedianya sarana-prasarana serta biaya yang cukup, jika tidak ditunjang dengan pengelolaan yang handal maka pencapaian tujuhan tidak akan tercapai secara optimal. Demikian pula bila pengelolaan baik, tetapi di dalam kondisi serba kekurangan, akan mengakibatkan hasil yang tidak optimal. Pengelolahan proses pendidikan meliputi ruang lingkup makro, meso dan mikro. Pengelolahan proses dalam lingkung makro berupa kebijakankebijakan pemerintah yang lazimnya dituangkan dalam bentuk UU pendidikan, peraturan pemerintah, SK metri, SK dirjen, serta dokumen-dokumen pemerintah tentang pendidikan tingkat nasional yang lain. ${ }^{4}$

Pengelolahan dalam ruang lingkup meso merupakan implikasi kebijakankebijakan nasional kedalam kebijakan oprasional dalam ruang lingkup wilayah dibawah tanggung jawab kakanwil dan Depdikbud. Pengelolahan dalam ruang lingkup meso merupakan implikasi kebijakan-kebijakan pendidikan yang berlangsung didalam lingkungan sekolah ataupun kelas, sanggar-sanggar belajar, dan satuansatuan pendidikan lainnya dalam masyarakat. ${ }^{5}$ Dalam ruang lingkup ini kepala

\footnotetext{
${ }^{4}$ Tamalene, 2011.Bahan Ajaran Pengantar Pendidikan.FKIP-Chamistry.Unkhair.Ternate

5 Saihu, S. (2019). KONSEP MANUSIA DAN IMPLEMENTASINYA DALAM PERUMUSAN TUJUAN PENDIDIKAN ISLAM MENURUT MURTADHA MUTHAHHARI. Andragogi: Jurnal Pendidikan Islam dan Manajemen Pendidikan Islam, 1(2), 197-217.

Saihu, S., \& Rohman, B. (2019). PEMBENTUKAN KARAKTER MELALUI MODEL PENDIDIKAN TRANSFROMATIFE LEARNING PADA SANTRI DI PONDOK PESANTREN NURUL IKHLAS BALI. Edukasi Islami: Jurnal Pendidikan Islam, 8(02), 435-452.

Saihu, S., \& Taufik, T. (2019). PERLINDUNGAN HUKUM BAGI GURU. Al Amin: Jurnal Kajian Ilmu dan Budaya Islam, 2(2), 105-116.

Saihu, S. (2020). KONSEP PEMBAHARUAN PENDIDIKAN ISLAM MENURUT FAZLURRAHMAN. Andragogi: Jurnal Pendidikan Islam dan Manajemen Pendidikan Islam, 2(1), 82-95.
} 
sekolah, guru, tutor, dan tenaga-tenaga pendidikan lainnya memegang peran penting di dalam pengelolahan pendidikan untuk untuk menciptakan kualitas proses dan pencapaian hasil pendidikan. misalnya seorang guru ia wajib menguasai pengelolahan kegiatan belajar mengajar, termasuk didalamnya pengelolaan kelas dan siswa. ${ }^{6}$

Tujuhan utama pengelolahan proses pendidikan yaitu terjadinya proses belajar dan pengalaman belajar yang optimal. Sebab berkembangnya tingkah laku pserta didik sebagi tujuhan belajar hanya dimungkinkan oleh adanya pengalaman belajar yang optimal itu. Disini jelas bahwa pendayagunaan teknologi pendidikan memegang peranan penting. Pengelolaan proses pendidikan harus memperhitungkan perkembangan IPTEK. Karena itu setiap guru wajib mengikuti dengan seksama novasi-inovasi pendidikan terutama diseminasikan secara luas oleh pemerintah serta PPSI, balajar tuntas (masteri learning), pendekatan CBSA dan keterampilan proses muatan local dalam kurikulum dan lain-lainnya agar dapat diambil manfaatnya. ${ }^{7}$

Di dalam UU No. 20/2003 tentang sisdiknas Pasal 1 ayat (1) dinyatakan bahwa pendidikan adalah usaha sadar dan terencana untuk mewujudkan suasana belajar dan proses pembelajaran agar peserta didik secara aktif mengembangkan potensi dirinya untuk memiliki kekuatan spiritual, keagamaan, pengendalian diri, kepribadian, kecerdasan, akhlak mulia serta keterampilan yang di perlukan dirinya, masyarakat, bangsa dan negara. 3. Orang tua memiliki prerogatif untuk memilih sekolah bagi anak-anaknya. Sekolah yang berkualitas semakin dicari, dan yang mutunya rendah akan di tinggalkan. 4. Penyelenggaraan pendidikan di sekolah (negeri atau swasta) tidak lepas dari nilai-nilai. Norma perilaku, keyakinan, maupun budaya. Apalagi sekolah yang di selenggarakan oleh yayasan islam. 5. Selama ini banyak orng mempersepsi prestasi sekolah hanya dilihat dari dimensi yang tampak, bisa di ukur dan dikuantifikasikan, terutama perolehan nilai UNAS dan kondisi fisik sekolah. 6. Budaya sekolah mempunyai dampak yang kuat terhadap prestasi kerja. ${ }^{8}$

Di dalam UUSPN No. 2/1989 pasal 39 ayat (2) ditegaskan bahwa isi kurikulum setiap jenis, jalur, dan jenjang pendidikan wajib memuat, antara lain Pendidikan agama. Dan Pendidikan Agama merupakan usaha untuk memperkuat iman dan ketakwaan terhadap Tuhan Yang Maha esa sesuai dengan agama yang dianut oleh peserta didik yang bersangkutan dengan memperhatikan tuntunan untuk menghormati agama lain dalam hubungan kerukunan antar umat beragama dalam masyarakat untuk mewujudkan persatuan nasional. Banyak orang merancukan pengertian istilah pendidikan agama islam dan pendidikan Islam . Kedua istilah ini

Saihu, S. (2020). ETIKA MENUNTUT ILMU MENURUT KITAB TA'LIM MUTA'ALIM. Al Amin: Jurnal Kajian Ilmu dan Budaya Islam, 3(1), 99-112.

Saihu, Aziz, A., Mubin, F., \& Sarnoto, A. Z. (2020). Design of islamic education based on local wisdom (An analysis of social learning theories in forming character through ngejot tradition in bali). International Journal of Advanced Science and Technology, 29(6), 1278-1293.

${ }^{6}$ Ali, 2007. Ilmu dan Aplikasi Pendidikan. grasindo. Bandung. IMTIMA

${ }^{7}$ Tamalene, 2011.Bahan Ajaran Pengantar Pendidikan.FKIP-Chamistry.Unkhair.Ternate

${ }^{8}$ Ronaldo, R., Zulfikar, A., Saihu, Ismail, \& Wekke, I. S. (2020). International relations of the asia pacific in the age of trump. Journal of Environmental Treatment Techniques, 8(1), 244-246.

Saihu, M. M., \& Aziz, A. (2020). Implementasi Metode Pendidikan Pluralisme Dalam Mata Pelajaran Pendidikan Agama Islam. Belajea; Jurnal Pendidikan Islam, 5(1), 131-150.

Saihu, M. (2019). Urgensi 'Urf dalam Tradisi Male dan Relevansinya dalam Dakwah Islam di JembranaBali. Jurnal Bimas Islam, 12(1), 173-201.

Saihu, S. (2020). The Effect of Using Talking Stick Learning Model on Student Learning Outcomes in Islamic Primary School of Jamiatul Khair, Ciledug Tangerang. Tarbawi: Jurnal Keilmuan Manajemen Pendidikan, 6(01), 61-68.

Saihu, S. (2020). Pendidikan sosial yang terkandung dalam Surat At-Taubah Ayat 71-72. Edukasi Islami: Jurnal Pendidikan Islam, 9(01), 127-148. 
dianggap sama sehingga ketika seseorang berbicara tentang pendidikan Islam ternyata isinya terbatas pada pendidikan agama Islam, atau sebaliknya ketika seseorang berbicara pendidikan agama Islam justru yang dibahas didalamnya adalah tentang pendidikan Islam. Padahal kedua istilah itu memiliki substansi yang berbeda(Muhaimin, 2006:3-4). PAI dibakukan sebagai nama kegiatan mendidikkan agama Islam. ${ }^{9}$ PAI sebagai mata pelajaran seharusnya dinamakan Agama Islam , karena yang diajarkan adalah agama Islam. Nama kegiatannya atau usaha-usaha dalam mendidikkan agama Islam disebut sebagai pendidikan agama Islam. Pendidikan Islam adalah nama sistem, yaitu sistem pendidikan yang islami, yang memiliki komponen-komponen yang secara keseluruhan mendukung terwujudnya sosok muslim yang di idealkan. Pendidikan Islam ialah pendidikan yang teoriteorinya disusun berdasarkan al-Qur an dan Hadits. Ahmadi mendefinisikan Pendidikan Islam sebagai usaha yang lebih khusus ditekankan untuk mengembangkan fitrah keberagamaan (religiousity), subyek didik agar lebih mampu memahami, menghayati dan mengamalkan ajaran-ajaran. Ahmadi menekankan kepada proses pengembangan potensi fitrah manusia untuk selalu melaksanakan ajaran-ajaran Islam, yang diawali dengan pemberian pengetahuan, pengertian dan pemahaman terhadap ajaran-ajaran Islam(Ahmadi, 2005:29) Pemahaman tentang PAI di sekolah dapat dilihat dari dua sudut pandang, yaitu PAI sebagai aktivitas dan PAI sebagai fenomena. PAI sebagai aktivitas berarti upaya yang secara sadar dirancang untuk membantu seseorang atau sekelompok orang dalam mengembangkan pandangan hidup (bagaimana orang akan menjalani dan memanfaatkan hidup dan kehidupannya), sikap hidup, dan keterampilan hidup baik yang bersifat manual (petunjuk praktis) maupun mental dan sikap sosial yang bernapaskan atau dijiwai oleh ajaran serta nilai-nilai Islam. ${ }^{10}$ Sedangkan sebagai fenomena adalah peristiwa perjumpaan antara dua orang atau lebih dan/atau penciptaan suasana yang dampaknya ialah berkembangnya suatu pandangan hidup yang bernafaskan atau dijiwai oleh ajaran dan nilai-nilai Islam, yang diwujudkan dalam sikap hidup serta keterampilan hidup pada salah satu atau beberapa pihak. ${ }^{11}$ Ahmad Tafsir mendefinisikan pendidikan Islam sebagai bimbingan yang diberikan oleh seseorang agar ia berkembang secara maksimal sesuai dengan ajaran Islam. Atau dengan kata lain, pendidikan Islam adalah bimbingan terhadap seseorang agar ia menjadi muslim semaksimal mungkin. Dengan definisi tersebut, Ahmad Tafsir menekankan kepada sifat dari aktivitas pendidikan Islam, yaitu berupa bimbingan sebagai suatu upaya yang tidak hanya ditekankan kepada aspek pengajaran (transfer ilmu pengetahuan), tapi berupa arahan, bimbingan, pemberian petunjuk dan pelatihan menuju terbentuknya pribadi muslim yang seutuhnya(Ahmad, 2006:32). Selanjutnya, Abdul Mudjib menyatakan bahwa pendidikan Islam adalah proses transinternalisasi pengetahuan dan nilai Islam kepada peserta didik melalui upaya pengajaran, pembiasaan, bimbingan, pengasuhan, pengawasan, dan pengembangan potensinya guna mencapai keselarasan dan kesempurnaan hidup di dunia dan akhirat. Dari beberapa definisi di atas dapat ditegaskan bahwa pendidikan Islam adalah proses pembentukan individu untuk mengembangkan fitrah keagamaannya, yang secara konseptual dipahami, dianalisis serta dikembangkan dari ajaran al-Qur an dan alSunnah melalui proses pembudayaan dan pewarisan dan pengembangan kedua sumber Islam tersebut pada setiap generasi dalam sejarah ummat Islam dalam mencapai kebahagian, kebaikan di dunia dan akhirat. Di dalam GBPP PAI di sekolah

\footnotetext{
${ }^{9}$ Muhaimin. 2001. Nuansa Baru Pendidikan Islam. Jakarta: PT. RajaGrafindo Persada

${ }^{10}$ Ahmadi, S. 2003. Kapita Selekta Pendidikan Islam. Bandung: Penerbit Angkasa

${ }^{11}$ Muhaimin. 2001. Nuansa Baru Pendidikan Islam. Jakarta: PT. RajaGrafindo Persada
} 
umum, ${ }^{12}$ dijelaskan bahwa pendidikan agama Islam adalah usaha sadar untuk menyiapkan siswa dalam meyakini, memahami, menghayati, dan mengamalkan agama Islam melalui kegiatan bimbingan, pengajaran, dan atau latihan dengan memperhatikan tuntunan untuk menghormati agama lain dalam hubungan kerukunan antar umat beragama dalam asyarakat untuk mewujudkan persatuan nasional. ${ }^{13}$

\section{B. Tujuhan pendidikan}

Tujuhan pendidikan memuat gambaran tentang nilai-nilai yang baik, luhur, pantas, benar dan indah untuk kehidupan. Karena itu tujuhan pendidikan mempunyai dua fungsi yaitu, memberikan arah kepada segenap kegiatan pendidikan mempunyai dua fungsi yaitu, memberikan arah kepada segenap kegiatan pendidikan dan merupakan suatu yang ingin dicapai segenap kegiatan pendidikan. Sebagai suatu komponen pendidikan, tujuhan pendidikan (Hamzuka 2011) menduduki posisi penting diantara komponen-komponen penting lainnya. Dapat dikatakan bahwa segenap komponen dari seluruh kegiatan pendidikan dilakukan semata-mata terarah kepada atau ditunjukan untuk mencapai tujuhan ttersebut. Dengan demikian maka kegiatan-kegiatan yang tidak relevan dengan tujuhan tersebut dianggap menyimpang, tidak fungsional, bahkan salah, sehingga perlu dicegah terjadinya. Disini terlihat bahwa tujuan pendidikan itu bersifat normative, yaitu mengandung unsur norma yang bersifat memaksa, tetapi tidak bertentangan dengan hakikat perkembangan pserta didik serta dapat diterimaholeh masyarakat sebagai nilai hidup yang baik. Sehubungan dengan nilai tujuhan yang sedemikian penting itu, maka menjadi keharusan bagi pendidikan untuk memahaminya, kekurangpahaman pendidik terhadapa tujuhan pendidikan dpoat mengakibatkan kesalahan di dalam melaksanakan pendidikan. Gejala demikian oleh Langeveld disebut salah teoritis. ${ }^{14}$

Tujuan pendidikan bersifat abstrak karena memuat nilai-nilai yang bersifat abstrak. Tujuan demikian bersifat umum, ideal dan kandungannya sangat luas sehingga sangat sulit untuk dilaksanakan di dalam praktek. Sedangkan pendidikan harus berupa tindakan yang ditujukan pada pserta didik dalam kondisi tertentu, tempat tertentu, dan waktu tertentu dengan menggunakan alat tertentu. Pelaksanaanya harus mungkin apabila tujuhan yang ingin dicapai itu dibuat jelas (eksplisit), kontret, dan lingkup kandungannya terbatas. dengan kata lain tujuhan umum perlu dirinci sehinggga menjadi tujuhan yang lebih khusus dan terbatas agar mudah direlisasikan dalam praktek. Mendidik pserta didik agar menjadi manusia berjiwa pancasila (sangat abstrak, umum, luas, dan sulit direalisasikan). Menumbuhkan jiwa demokratis pada diri pserta didik (masi bersifat umum, belum mudah direalisasikan). Memberikan

12 Aziz, A., \& Saihu, S. (2019). Interpretasi Humanistik Kebahasaan: Upaya Kontekstualisasi Kaidah Bahasa Arab. Arabiyatuna: Jurnal Bahasa Arab, 3(2), 299-214

Saihu, S. (2019). PENDIDIKAN KARAKTER BERBASIS KEARIFAN LOKAL (STUDI DI JEMBRANA BALI). Edukasi Islami: Jurnal Pendidikan Islam, 8(01), 69-90.

Şahin, C. RELIGIA.

Saihu, S., \& Mailana, A. (2019). Teori pendidikan behavioristik pembentukan karakter masyarakat muslim dalam tradisi Ngejot di Bali. Ta'dibuna: Jurnal Pendidikan Islam, 8(2), 163-176.

Mubin, F. KEADILAN DALAM GENDER: KAJIAN KEPEMIMPINAN WANITA DALAM ISLAM1,

Saihu, M. (2019). Merawat Pluralisme Merawat Indonesia (Potret Pendidikan Pluralisme Agama Di JembranaBali). Deepublish.

Mubin, F. (2019). TAFSIR EMANSIPATORIS: PEMBUMIAN METODOLOGI TAFSIR PEMBEBASAN. Mumtaz: Jurnal Studi Al-Quran dan Keislaman, 3(1), 131-151.

Mubin, F. MODEL-MODEL PEMBELAJARAN BERBASIS MADRASAH DAN KEGIATAN LAIN YANG DIPERLUKAN DI DALAMNYA (FAKTOR PENDUKUNGNYA).

${ }^{13}$ Daulay, H. P. 2007. Sejarah Pertumbuhan dan Pembaruan Pendidikan Islam di Indonesia. Jakarta: Kencana

14 Agus, Bustanuddin. Pengembangan Ilmu-ilmu Sosial Studi Banding antara Pandangan Ilmiah dan Ajaran Islam. Jakarta: Gema Insani, 1999. 
kesempatan kepada pserta didik untuk mengajukan pendapat. (lingkungannya terbatas dan mudah dilaksanakan).

Ada beberapa hal yang menyebabkan mengapa tujuan khusus itu diperlukan antara lain:

a. Pengkhususan tujuan memungkinkan dilaksanakannya tujuan umum melalui proses pendidikan.

b. Adanya kekhususan dari pserta didik, yaitu yang berkenaan dengan jenis kelamin, pembawaan dan minatnya, kemampuan orang tuanya, lingkungan masyarakat.

c. Kepribadian yang menjadi sasaran untuk dibentuk atau dikembangkan bersifat kompleks sehingga perlu dirinci dan dikhususkan, aspek apa yang dikembangkan.

d. Adanya tahapan-tahapan perkembangan pendidikan.

e. Adanya kekhususan masing-masing lembaga penyelenggaraan pendidikan. kesehatan, pertanian, dan lain-lain ataupun jalur pendidikan seperti jalur pendidikan sekolah dan jalur pendidikan luar sekolah.

f. Ananya tuntutan persyaratan pekerjaan yang harus dipenuhi oleh pserta didik sebagai pilihannya.

g. Diperlukan teknik tertentu yang menunjang pencapaian tujuan lebih lanjut misalnya membaca dan menulis dalam waktu yang relatif pendek.

h. Adanya kondisi situasional, yaitu pristiwa-pristiwa yang secara kebetulan muncul tampa direncanakan.

i. Kemampuan yang ada pada pendidikan.

Di dalam praktek pendidikan khususnya pada sistem persekolahan, di dalam rentang antara tujuan umum dengan tujuan yang sangat khusus terdapat sejumlah tujuan antara. Tujuan antara berfungsi untuk menjembatin pencapaian tujuan umum dari sejumlah tujuan rincian khsus. Umumnya ada 4 jengjang tujuan yang didalamnya terdapat tujuan antara, yaitu: tujuan umum, tujuan instrukdionsl.

a. Tujuan umum juga disebut tujuan total, tujuan yang sempurna atau tujuan akhir, Dalam hal ini kohnstan dan Gunning mengatakan bahwa tujuan akhir dari pendidikan yaitu untuk menentukan insan kamil atau manusia sempurna. Manusia dapat dikatakan seabagai insan kamil, apanbila dalam hidupnya menunjukan adanya keselarasan/harmonis anatara jasmaniah dan rohaniah. harmonis anatar segi-segi dalam kejiwaan, antara kehidupan sebagai individu dan kehidupan bersama. Kehidudpan sebagai insan kamil adalah merupakan suatu kehiidupan di mana terjamin adanaya ketiga inti hakikat manusia. Yaitu, manusia sebagai makhluk individual, makhluk sosisal dan makhluk susila.

b. Tujuan institusional yaitu tujuan yang menjadi tegas dari lembaga pendidikan tertentu untuk mencapainya. Misalnya tujuan npendidikan tingkat SD berbeda dari tujuan tingkat menengah, dan seterusnya.

c. Tujuan kurikuler, yaitu tujuan bidang studi atau tujuan bidang mata pelajaran.

d. Tujuan instruksional, materi kurikulum yang berupa bidang studi-bidang studi terdiri dari pokok-pokok bahasa dan sub-pokok bahasan. Tujuaan bahasan dan tujuan sub-pokok bahasan disebut tujuan instruksional, yaitu penguasaan materi pokok bahasan/sub pokok bahasa. Tujuan pokok bahasa disebut tujuan instruksional umum (TIU) dan tujuan sub-pokok bahasan disebut tujuan instruksional khusus (TIK) merupakan tujuan yang terletak 
pada jengejang terbawah dan paling terbatas ruang lingkupnya kemudian bersifat oprasional dan terkerjakan. ${ }^{15}$

Secara keseluruhan macam-macam tujuan tersebut merupakan kebulatan. Tujuan umum memberikan arah kepada semua tujuan yang lebih rinci dan yang jengjangnya lebih rendah. sebaliknya tujuan yang lebih khusus menunjang pencapaian tujuan yang lebih luas dan jengjangannya lebih tinggi untuk sampai kepada tujuan umum. Tujuan pendidikan akan menentukan kearah mana anak didik akan dibawa. Disamping itu pendidikan berfungsi untuk mengembangkan kemampuan serta meningkatkan mutu kehidupan dan mertabat manusia indonesia. Tujuan pendiidkan tidak berdiri sendiri, melaikan dirumuskan atas dasar sikap hidup bangsa dan cita-cita negara dimana pendidikan itu dilaksanakan. Sikap dasar itu dilandasi oleh menunjang pencapaian tujuan yang lebih luas dan jengjangannya yang lebih tinggi untuk sampai kepada tujuan umum.

\section{Memahami Pendidikan Agama Islam}

Banyak orang merancukan pengertian istilah "pendidikan agama islam" dan "pendidikan Islam". Kedua istilah ini dianggap sama sehingga ketika seseorang berbicara tentang pendidikan Islam ternyata isinya terbatas pada pendidikan agama Islam, atau sebaliknya ketika seseorang berbicara pendidikan agama Islam justru yang dibahas di dalamnya adalah tentang pendidikan Islam. Padahal kedua istilah itu memiliki substansi yang berbeda. ${ }^{16}$ PAI dibakukan sebagai nama kegiatan mendidikkan agama Islam. PAI sebagai mata pelajaran seharusnya dinamakan "Agama Islam", karena yang diajarkan adalah agama Islam. Nama kegiatannya atau usaha-usaha dalam mendidikkan agama Islam disebut sebagai pendidikan agama Islam. Sedangkan pendidikan Islam adalah nama sistem, yaitu sistem pendidikan yang islami, yang memiliki komponen-komponen yang secara keseluruhan mendukung terwujudnya sosok muslim yang diidealkan. Pendidikan Islam ialah pendidikan yang teoriteorinya disusun berdasarkan al-Qur'an dan Hadits. ${ }^{17}$

Pemahaman tentang PAI di sekolah dapat dilihat dari dua sudut pandang, yaitu PAI sebagai aktivitas dan PAI sebagai fenomena. PAI sebagai aktivitas berarti upaya yang secara sadar dirancang untuk membantu seseorang atau sekelompok orang dalam mengembangkan pandangan hidup (bagaimana orang akan menjalani dan memanfaatkan hidup dan kehidupannya), sikap hidup, dan keterampilan hidup-- baik yang bersifat manual (petunjuk praktis) maupun mental--dan sikap sosial yang bernapaskan atau dijiwai oleh ajaran serta nilai-nilai Islam. Sedangkan sebagai fenomena adalah peristiwa perjumpaan antara dua orang atau lebih dan/atau penciptaan suasana yang dampaknya ialah berkembangnya suatu pandangan hidup yang bernafaskan atau dijiwai oleh ajaran dan nilai-nilai Islam, yang diwujudkan dalam sikap hidup serta keterampilan hidup pada salah satu atau beberapa pihak. ${ }^{18}$

Di dalam GBPP PAI (1999) di sekolah umum, dijelaskan bahwa PAI adalah usaha sadar untuk menyiapkan siswa dalam meyakini, memahami, menghayati, dan mengamalkan agama Islam melalui kegiatan bimbingan, pengajaran, dan/atau latihan dengan memerhatikan tuntutan untuk menghormati agama lain dalam hubungan kerukunan antar umat beragama dalam masyarakat untuk mewujudkan persatuan

\footnotetext{
15 Djamas, Nurhayati. Dinamika Pendidikan Islam di Indonesia Pascakemerdekaan. Jakarta: Rajawali Press, 2009.

16 Muhaimin, Nuansa Baru Pendidikan Islam, Mengurai Benang Kusut Dunia Pendidikan (Jakarta: RajaGrafindo Persada, 2006), hlm.3-4.

${ }^{17}$ Ahmadi, Ideologi Pendidikan Islam (Yogyakarta: Pustaka Pelajar, 2005), hlm. 29.

18 Muhaimin, Rekonstruksi Pendidikan Islam, dari Paradigma Pengembangan, Manajemen Kelembagaan, Kurikulum hingga Strategi Pembelajaran (Jakarta: Rajawali Press, 2009), hlm. 51.
} 
nasional. ${ }^{19}$ Ruang lingkup materi dari kurikulum pendidikan agama Islam untuk pencapaian tujuan tersebut meliputi al-Qur'an, keimanan (akidah), akhlak, fiqh, dan bimbingan ibadah, serta tarikh Islam. ${ }^{20}$

\section{Pengembangan Pendidikan Islam}

Pengembangan dapat bermakna kuantitatif dan kualitatif. Secara kuantitatif bagaimana menjadikan pendidikan agama islam yang hanya dua atau tiga jam pelajaran itu dapat lebih meluas dan merata pengaruhnya baik di dalam maupun di luar sekolah. Secara kualitatif bagaimana menjadikan pendidikan agama islam lebih baik, bermutu dan lebih maju sejalan dengan ide-ide dasar atau nilai-nilai islam itu sendiri yang seharusnya selalu berada di depan dalam merespons dan mengantisipasi berbagai tantangan hidup dan kehidupan.

Perlunya pendidikan agama islam dikembangkan menjadi budaya sekolah, yaitu:

1. Pancasila sebagai falsafah negara atau bangsa Indonesia mendudukan sila pertama Ketuhanan Yang Maha Esa sebagai core atau inti yang mewarnai dan menjiwai sila-sila berikut:

2. Di dalam UU No. 20/2003 tentang sisdiknas Pasal 1 ayat (1) dinyatakan bahwa pendidikan adalah usaha sadar dan terencana untuk mewujudkan suasana belajar dan proses pembelajaran agar peserta didik secara aktif mengembangkan potensi dirinya untuk memiliki kekuatan spiritual, keagamaan, pengendalian diri, kepribadian, kecerdasan, akhlak mulia serta keterampilan yang di perlukan dirinya, masyarakat, bangsa dan negara.

3. Orang tua memiliki prerogatif untuk memilih sekolah bagi anak-anaknya. Sekolah yang berkualitas semakin dicari, dan yang mutunya rendah akan di tinggalkan.

4. Penyelenggaraan pendidikan di sekolah (negeri atau swasta) tidak lepas dari nilai-nilai. Norma perilaku, keyakinan, maupun budaya. Apalagi sekolah yang di selenggarakan oleh yayasan islam.

5. Selama ini banyak orng mempersepsi prestasi sekolah hanya dilihat dari dimensi yang tampak, bisa di ukur dan dikuantifikasikan, terutama perolehan nilai UNAS dan kondisi fisik sekolah.

6. Budaya sekolah mempunyai dampak yang kuat terhadap prestasi kerja.

Dalam realitas kehidupan sehari-hari sering timbul pertanyaan: apa saja aspekaspek kehidupan itu? Apakah agama merupakan bagian dari aspek kehidupan, sehingga hidup beragama berarti menjalankan salah satu aspek dari berbagai aspek kehidupan, ataukah agama merupakan sumber nilai-nilai dan operasional kehidupan, sehingga agama akan mewarnai segala aspek kehidupan itu sendiri?. Dalam konteks inilah para pemikir dan pengembang pendidikan pada umumnya mempunyai pandangan yang berbeda-beda. Perbedaan tersebut pada gilirannya melahirkan beberapa model dalam pengembangan PAI sebagaimana uraian berikut:

a. Model Dikotomis

Pada model ini, aspek kehidupan dipandangan sangat sederhana, dan kata kuncinya adalah dikotomi atau diskrit. Segala sesuatu hanya dilihat dari dua sisi yang berlawanan. Pandangan dikotomis tersebut pada gilirannya dikembangkan dalam memandang aspek kehidupan dunia dan akhirat, kehidupan jasmani dan rohani, sehingga pendidikan agama Islam hanya

\footnotetext{
${ }^{19}$ Muhaimin, Paradigma Pendidikan Islam, hlm. 75-76.

${ }^{20}$ Nurhayati Djamas, Dinamika Pendidikan Islam di Indonesia Pascakemerdekaan (Jakarta: Rajawali Press, 2009), hlm.139.
} 
diletakkan pada aspek kehidupan akhirat saja atau kehidupan rohani saja. Dengan demikian, pendidikan agama dihadapkan dengan pendidikan non agama, pendidikan keislaman dengan nonkeislaman, demikian seterusnya. $^{21}$

Pandangan semacam itu akan berimplikasi pada pengembangan pendidikan agama Islam yang hanya berkisar pada aspek kehidupan ukhrowi yang terpisah dengan kehidupan duniawi, atau aspek kehidupan rohani yang terpisah dari kehidupan jasmani. Pendidikan (agama) Islam hanya mengurusi persoalan ritual dan spiritual, sementara kehidupan ekonomi, politik, seni-budaya, ilmu pengetahuan dan teknologi, seni dan sebagainya dianggap sebagai urusan duniawi yang menjadi garapan bidang pendidikan nonagama. Pandangan dikotomis inilah yang menimbulkan dualisme dalam sistem pendidikan, yaitu istilah pendidikan agama dan nonagama. Sikap dikotomi (dualisme) ini terkait erat dengan world view umat Islam dalam memandang dan menempatkan dua sisi ilmu, yaitu 'ilm al-dînîyah dan 'ilm ghair al-dînîyah. ${ }^{22}$ Demikian pula pendekatan yang dipergunakan lebih bersifat keagamaan yang normatif, doktriner dan absolutis. Peserta didik diarahkan untuk menjadi pelaku (actor) yang loyal, memiliki sikap commitment (keberpihakan), dan dedikasi (pengabdian) yang tinggi terhadap agama yang dipelajari. Sementara itu, kajian-kajian keilmuan yang bersifat empiris, rasional, analitis-kritis, dianggap dapat menggoyahkan iman, sehingga perlu ditindih oleh pendekatan yang normatif dan doktriner tersebut. Pola dikotomi yang demikian, telah menimbulkan sejumlah efek negatif. Abdurrahman Mas'ud dalam salah satu penelitiannya-- sebagaimana dikutip Ma'arif--menunjukkan bahwa cara pandang yang dikotomik tersebut akhirnya telah membawa kemunduran dalam dunia pendidikan Islam. Di antaranya adalah menurunnya tradisi belajar yang benar di kalangan muslim, layunya intelektualisme Islam, melanggengkan supremasi ilmu-ilmu agama yang berjalan secara monotomik, kemiskinan penelitian empiris serta menjauhkan disiplin filsafat dari pendidikan Islam. ${ }^{23}$

b. Model Mekanisme

Model mekanisme memandang kehidupan terdiri atas berbagai aspek, dan pendidikan dipandang sebagai penanaman dan pengembangan seperangkat nilai kehidupan. ${ }^{24}$ yang masing-masing bergerak dan berjalan menurut fungsinya, bagaikan sebuah mesin yang terdiri atas beberapa komponen atau elemen-elemen, yang masing-masing menjalankan fungsinya sendirisendiri, dan antara satu dengan lainnya bisa berkonsultasi atau tidak. Aspek-aspek atau nilai-nilai kehidupan itu sendiri terdiri atas nilai agama, nilai individu, nilai sosial, nilai politik, nilai ekonomi, nilai rasional, nilai estetik, nilai biofisik, dan lain-lain. Demikian juga dalam proses pendidikan dibutuhkan sistem nilai agar dalam pelaksanaannya berjalan dengan arah yang pasti, karena berpedoman pada garis kebijaksanaan yang

\footnotetext{
${ }^{21}$ Muhaimin, Rekonstruksi Pendidikan Islam, hlm. 60.

${ }^{22}$ Poedjawajatna, Tahu dan Pengetahuan: Pengantar ke Ilmu dan Filsafat Ilmu (Jakarta: Bina Aksara, 1983), hlm. 62-73.

${ }^{23}$ Syamsul Maarif, Revitalisasi Pendidikan Islam (Yogyakarta: Graha Ilmu, 2007), hlm.15

${ }^{24}$ Murtadha Mutahhari, Perspektif al-Qur'an tentang Manusia dan Agama (Bandung: Mizan, 1984), hlm. 82-93.
} 
ditimbulkan oleh nilai-nilai fundamental, misalnya nilai agama. ${ }^{25}$ ilmiah, sosial, ekonomi, kualitas kecerdasan dan sebagainya.

Oleh karena itu, jika kita membahas nilai-nilai pendidikan, akan jelas melalui rumusan dan uraian tentang tujuan pendidikan, sebab di dalam rumusan tujuan pendidikan itu tersimpul dari semua nilai pendidikan yang hendak diwujudkan di dalam pribadi peserta didik. ${ }^{26}$ Demikian pula, jika berbicara tentang tujuan pendidikan Islam, berarti berbicara nilai-nilai ideal yang bercorak Islami. Hal ini mengandung makna bahwa tujuan pendidikan Islam adalah tujuan yang merealisasi idealitas Islami. Sedang idealitas Islami itu sendiri pada hakikatnya adalah mengandung nilai perilaku manusia yang didasari atau dijiwai oleh iman dan taqwa kepada Allah sebagai sumber kekuasaan mutlak yang harus ditaati. ${ }^{27}$ Dengan demikian, aspek atau nilai agama merupakan salah satu aspek atau nilai kehidupan dari aspek-aspek kehidupan lainnya. Hubungan antara nilai agama dengan nilai-nilai lainnya kadangkadang bersifat horizontal-lateral (independent) atau bersifat lateralsekuensial, tetapi tidak sampai pada vertikal linier. ${ }^{28}$ Relasi yang bersifat horizontal-lateral (independent), mengandung arti bahwa beberapa mata pelajaran yang ada dan pendidikan agama mempunyai hubungan sederajat yang independen, dan tidak saling berkonsultasi. Relasi yang bersifat lateral-sekuensial, berarti di antara masing-masing mata pelajaran tersebut mempunyai relasi sederajat yang bisa saling berkonsultasi. Sedangkan relasi vertikal linier berarti mendudukkan pendidikan agama sebagai sumber nilai atau sumber konsultasi, sementara seperangkat mata pelajaran yang lain termasuk pengembangan nilai insani yang mempunyai relasi vertikal linier dengan agama. Dalam konteks tersebut, selama ini di sekolah-sekolah masih ada proses sekularisasi ilmu, yakni pemisahan antara ilmu agama dan pengetahuan umum. Nilai-nilai keimanan dan ketakwaan seolaholah hanya merupakan bagian dari mata pelajaran pendidikan agama, sementara mata pelajaran yang lain mengajarkan ilmunya seolah-olah tidak ada hubungannya dengan masalah nilai keimanan dan ketakwaan. ${ }^{29}$ Dampak berupa gejala kegersangan batin dan kejiwaan modern adalah konsekuensi dari hal itu. Bahkan pendidikan di dunia muslim pun berurat berakar mengadopsi konsep sekuler yang dikotomis dan tidak utuh. ${ }^{30}$ Model tersebut tampak dikembangkan pada sekolah yang di dalamnya diberikan seperangkat mata pelajaran atau ilmu pengetahuan, yang salah satunya adalah mata pelajaran pendidikan agama yang hanya diberikan 2 atau 3 jam pelajaran per minggu, dan didudukkan sebagai mata pelajaran, yakni sebagai upaya pembentukan kepribadian yang religius. Kebijakan ini sangat prospektif dalam membangun watak, moral dan peradaban bangsa yang bermartabat. Namun demikian, dalam realitasnya pendidikan agama Islam sering termarginalkan, bahkan guru PAI di sekolah pun kadang-

\footnotetext{
${ }^{25}$ Soekarno dan Ahmad Supardi, Sejarah dan Filsafat Pendidikan Islam (Bandung: Angkasa, 1983), hlm.19

${ }^{26}$ Mohammad Noor Syam, Filsafat Pendidikan dan Dasar Filsafat Pendidikan Pancasila (Surabaya: Usaha Nasional, 1986), hlm.140.

${ }^{27}$ M. Arifin, Filsafat Pendidikan Islam (Jakarta: Bumi Aksara, 1994), hlm. 119.

${ }^{28}$ Muhaimin, Pengembangan Kurikulum Pendidikan, hlm.36.

${ }^{29}$ Muhaimin, Pengembangan Kurikulum Pendidikan, hlm.36.

${ }^{30}$ Abdurrahmansyah, Wacana Pendidikan Islam, Khazanah Filosofis dan Implementasi Kurikulum, Metodologi dan Tantangan Pendidikan Moralitas (Yogyakarta: Global Pustaka Utama, 2005), hlm. 145.
} 
kadang terhambat karirnya untuk menggapai jabatan fungsional tertinggi, karena tidak tersedia program studi sebagai induknya.25 Kebijakan tentang pembinaan pendidikan agama Islam secara terpadu di sekolah umum misalnya, antara lain menghendaki agar pendidikan agama dan sekaligus para guru agamanya mampu memadukan antara mata pelajaran agama dengan pelajaran umum. Kebijakan ini akan sulit diimplementasikan pada sekolah yang cukup puas hanya mengembanhkan pola relasi horizontal-lateral (independent). Barangkali kebijakan tersebut relatif mudah diimplementasikan pada lembaga pendidikan yang mengembangkan pola lateral-sekuensial. Hanya saja implikasi dari kebijakan tersebut adalah para guru agama harus menguasai ilmu agama dan memahami substansi ilmu-ilmu umum, sebaliknya guru umum dituntut untuk menguasai ilmu umum (bidang keahliannya) dan memahami ajaran dan nilai-nilai agama. Bahkan guru agama dituntut untuk mampu menyusun buku-buku teks keagamaan yang dapat menjelaskan hubungan antara keduanya. ${ }^{31}$

c. Model Organism/Sistemik

Meminjam istilah biologi, organism dapat berarti susunan yang bersistem dari berbagai bagian jasad hidup untuk suatu tujuan. Dalam konteks pendidikan Islam, model organism bertolak dari pandangan bahwa aktivitas kependidikan merupakan suatu sistem yang terdiri atas komponen-komponen yang hidup bersama dan bekerja sama secara terpadu menuju tujuan tertentu, yaitu terwujudnya hidup yang religius atau dijiwai oleh ajaran dan nilai-nilai agama. ${ }^{32}$ Pandangan tersebut menggarisbawahi pentingnya kerangka pemikiran yang dibangun dari fundamental doctrines dan fundamental values yang tertuang dan terkandung dalam al-Qur'an dan alSunnah al-Shahîhah sebagai sumber pokok. Ajaran dan nilai-nilai ilahi didudukkan sebagai sumber konsultasi yang bijak, sementara aspek kehidupan lainnya didudukkan sebagai nilainilai insani yang mempunyai hubungan vertikal-linier dengan nilai ilahi/agama. ${ }^{33}$ Nilai ilahi dalam aspek teologi tak pernah mengalami perubahan, sedangkan aspek amaliahnya mungkin mengalami perubahan sesuai dengan tututan zaman dan lingkungan. Sebaliknya nilai insani selamanya mengalami perkembangan dan perubahan menuju ke arah yang lebih maju dan lebih tinggi. Tugas pendidikan adalah memadukan nilainilai baru dengan nilai-nilai lama secara selektif, inovatif, dan akomodatif guna mendinamisasikan perkembangan pendidikan yang sesuai dengan tuntutan zaman dan keadaan, tanpa meninggalkan nilai fundamental yang menjadi tolok ukur bagi nilai-nilai baru. Melalui upaya semacam itu, maka sistem pendidikan Islam diharapkan dapat mengintegrasikan nilai-nilai ilmu pengetahuan, nilai-nilai agama dan etik, serta mampu melahirkan manusia-manusia yang menguasai dan menerapkan ilmu pengetahuan, teknologi dan seni, memiliki kematangan profesional, dan sekaligus hidup di dalam nilai-nilai agama. Paradigma tersebut tampaknya mulai dirintis dan dikembangkan dalam sistem pendidikan di madrasah, yang dideklarasikan sebagai sekolah umum yang berciri khas agama Islam, atau

\footnotetext{
${ }^{31}$ Abdurrahmansyah, Wacana Pendidikan Islam, Khazanah Filosofis dan Implementasi Kurikulum, Metodologi dan Tantangan Pendidikan Moralitas (Yogyakarta: Global Pustaka Utama, 2005), hlm. 37-38.

${ }^{32}$ Muhaimin, Rekonstruksi Pendidikan Islam, hlm. 67

${ }^{33}$ Muhaimin, Rekonstruksi Pendidikan Islam, hlm. 67.
} 
sekolah-sekolah (swasta) Islam unggulan. Kebijakan pengembangan madrasah berusaha mengakomodasikan tiga kepentingan utama, yaitu: pertama, sebagai wahana untuk membina roh atau praktik hidup keislaman; kedua, memperjelas dan memperkokoh keberadaan madrasah sederajat dengan sistem sekolah, sebagai pembinaan warga negara yang cerdas berpengetahuan, berkepribadian, serta produktif; dan ketiga, mampu merespon tuntutan-tuntutan masa depan dalam arti sanggup melahirkan manusia yang memiliki ke- siapan memasuki era globalisasi, industrialisasi maupun era informasi. ${ }^{34}$ Maka dari itu, model organisme/sistemik dapat diimplementasikan dalam pengembangan pendidikan agama Islam di sekolah, mengingat kegiatan pendidikan agama yang berlangsung selama ini lebih banyak bersikap menyendiri, kurang berinteraksi dengan kegiatankegiatan pendidikan lainnya. Cara kerja semacam ini kurang efektif untuk keperluan penanaman suatu perangkat nilai yang kompleks. Selain itu, metodologi pendidikan agama kurang mendorong penjiwaan terhadap nilai-nilai kegamaan serta terbatasnya bahan-bahan bacaan keagamaan. Buku-buku paket pendidikan agama saat ini belum memadai untuk membangun kesadaran beragama, memberikan keterampilan fungsional keagamaan dan mendorong perilaku bermoral dan berakhlak mulia pada peserta didik.

\section{BAB III \\ PENUTUP}

\section{A. Kesimpulan}

Proses dan pengembangan pendidikan islam sangatlah penting untuk mendukung kelangsuang sutu proses pendiidikan dengan adanya tujuan dan pengembangan keilmuan keislaman. Pendidikan merupakan kegiatan memobilisasi segenap komponen pendidikan oleh pendidikan terarah kepada pencapaian tujuhan pendidikan. bagaimana proses pendidikan itu dilaksanakan

\footnotetext{
${ }^{34}$ Muhaimin, Rekonstruksi Pendidikan Islam, hlm. 68.
} 
sangat menentukan kualitas hasil pencapaian tujuhan pendidikan. Pendidikan memuat gambaran tentang nilai-nilai yang baik, luhur, pantas, benar dan indah untuk kehidupan. Karena itu tujuhan pendidikan mempunyai dua fungsi yaitu, memberikan arah kepada segenap kegiatan pendidikan mempunyai dua fungsi yaitu, memberikan arah kepada segenap kegiatan pendidikan dan merupakan suatu yang ingin dicapai segenap kegiatan pendidikan. Model pengembangannya perlu direkonstruksi, dari model yang bersifat dikotomis dan mekanisme ke arah model organisme atau sistemik. Hanya saja untuk merombak model tersebut diperlukan kemampuan guru PAI dan political will dari para pengambil kebijakan, termasuk di dalamnya para pimpinan lembaga pendidikan itu sendiri

\section{B. Saran}

Disadari bahwa dari penyajian di atas, baik aspek penulisan maupun pembahasannya masih jauh dari harapan dan kesempurnaan. Dalam menggali ilmu khususnya proses dan pengembangan pendidikan islam.

Selanjutnya, penulis berharap semoga makala ini bermanfaat dan memberikan tambahan ilmu pengetahuan untuk kita semua dan semoga ilmu yang kita dapat dalam makala ini bisa di pakai dan dipergunakan secara baik

\section{DAFTAR PUSTAKA}

Abdurrahmansyah, Wacana Pendidikan Islam, Khazanah Filosofis dan Implementasi

Kurikulum, Metodologi dan Tantangan Pendidikan Moralitas (Yogyakarta: Global

Pustaka Utama, 2005

Agus, Bustanuddin. Pengembangan Ilmu-ilmu Sosial Studi Banding antara Pandangan Ilmiah dan Ajaran Islam. Jakarta: Gema Insani, 1999.

Ahmadi, Ideologi Pendidikan Islam (Yogyakarta: Pustaka Pelajar, 2005), hlm. 29.

Ahmadi, S. 2003. Kapita Selekta Pendidikan Islam. Bandung: Penerbit Angkasa

Ali, 2007. Ilmu dan Aplikasi Pendidikan. grasindo. Bandung. IMTIMA

Aziz, A., \& Saihu, S. (2019). Interpretasi Humanistik Kebahasaan: Upaya Kontekstualisasi

Kaidah Bahasa Arab. Arabiyatuna: Jurnal Bahasa Arab, 3(2), 299-214

Daulay, H. P. 2007. Sejarah Pertumbuhan dan Pembaruan Pendidikan Islam di Indonesia. Jakarta: Kencana

Djamas, Nurhayati. Dinamika Pendidikan Islam di Indonesia Pascakemerdekaan. Jakarta: Rajawali Press, 2009.

M. Arifin, Filsafat Pendidikan Islam (Jakarta: Bumi Aksara, 1994)

Mohammad Noor Syam, Filsafat Pendidikan dan Dasar Filsafat Pendidikan Pancasila (Surabaya: Usaha Nasional, 1986)

Mubin, F. (2019). TAFSIR EMANSIPATORIS: PEMBUMIAN METODOLOGI TAFSIR PEMBEBASAN. Mumtaz: Jurnal Studi Al-Quran dan Keislaman, 3(1), 131-151.

Mubin, F. KEADILAN DALAM GENDER: KAJIAN KEPEMIMPINAN WANITA DALAM ISLAM1,

Mubin, F. MODEL-MODEL PEMBELAJARAN BERBASIS MADRASAH DAN KEGIATAN LAIN YANG DIPERLUKAN DI DALAMNYA (FAKTOR PENDUKUNGNYA).

Muhaimin, Nuansa Baru Pendidikan Islam, Mengurai Benang Kusut Dunia Pendidikan (Jakarta: RajaGrafindo Persada, 2006), hlm.3-4.

Muhaimin, Paradigma Pendidikan Islam, hlm. 75-76.

Muhaimin, Paradigma Pendidikan Islam,Upaya Mengefektifkan Pendidikan Agama Islam di Sekolah (Bandung: Remaja Rosdakarya, 2004)

Muhaimin, Pengembangan Kurikulum Pendidikan Agama Islam di Sekolah, Madrasah, dan Perguruan Tinggi (Jakarta: RajaGrafindo Persada, 2009)

Muhaimin, Pengembangan Kurikulum Pendidikan,

Muhaimin, Rekonstruksi Pendidikan Islam, 
Muhaimin, Rekonstruksi Pendidikan Islam, dari Paradigma Pengembangan, Manajemen Kelembagaan, Kurikulum hingga Strategi Pembelajaran (Jakarta: Rajawali Press, 2009), hlm. 51. Muhaimin. 2001. Nuansa Baru Pendidikan Islam. Jakarta: PT. RajaGrafindo Persada Murtadha Mutahhari, Perspektif al-Qur'an tentang Manusia dan Agama (Bandung: Mizan, 1984)

Nurhayati Djamas, Dinamika Pendidikan Islam di Indonesia Pascakemerdekaan (Jakarta: Rajawali Press, 2009), hlm.139.

Poedjawajatna, Tahu dan Pengetahuan: Pengantar ke Ilmu dan Filsafat Ilmu (Jakarta: Bina Aksara, 1983)

Ronaldo, R., Zulfikar, A., Saihu, Ismail, \& Wekke, I. S. (2020). International relations of the asia pacific in the age of trump. Journal of Environmental Treatment Techniques, 8(1), 244-246.

Şahin, C. RELIGIA.

Saihu, Aziz, A., Mubin, F., \& Sarnoto, A. Z. (2020). Design of islamic education based on local wisdom (An analysis of social learning theories in forming character through ngejot tradition in bali). International Journal of Advanced Science and Technology, 29(6), 1278-1293.

Saihu, M. (2019). Urgensi 'Urf dalam Tradisi Male dan Relevansinya dalam Dakwah Islam di Jembrana-Bali. Jurnal Bimas Islam, 12(1), 173-201.

Saihu, M. (2019). Merawat Pluralisme Merawat Indonesia (Potret Pendidikan Pluralisme Agama Di Jembrana-Bali). Deepublish.

Saihu, M. M., \& Aziz, A. (2020). Implementasi Metode Pendidikan Pluralisme Dalam Mata Pelajaran Pendidikan Agama Islam. Belajea; Jurnal Pendidikan Islam, 5(1), 131-150.

Saihu, S. (2019). IMPLEMENTASI MANAJEMEN BALANCED SCORECARD DI PONDOK PESANTREN JAM'IYYAH ISLAMIYYAH TANGERANG SELATAN. Mumtaz: Jurnal Studi Al-Quran dan Keislaman, 3(1), 1-22.

Saihu, S. (2019). KOMUNIKASI PENDIDIK TERHADAP ANAK BERKEBUTUHAN KHUSUS DI SEKOLAH KHUSUS ASY-SYIFA LARANGAN. Andragogi: Jurnal Pendidikan Islam dan Manajemen Pendidikan Islam, 1(3), 418-440.

Saihu, S. (2019). KONSEP MANUSIA DAN IMPLEMENTASINYA DALAM PERUMUSAN TUJUAN PENDIDIKAN ISLAM MENURUT MURTADHA MUTHAHHARI. Andragogi: Jurnal Pendidikan Islam dan Manajemen Pendidikan Islam, 1(2), 197-217.

Saihu, S. (2019). PENDIDIKAN KARAKTER BERBASIS KEARIFAN LOKAL (STUDI DI JEMBRANA BALI). Edukasi Islami: Jurnal Pendidikan Islam, 8(01), 69-90.

Saihu, S. (2019). Pendidikan Pluralisme Agama: Kajian tentang Integrasi Budaya dan Agama dalam Menyelesaikan Konflik Sosial Kontemporer. Jurnal Indo-Islamika, 9(1), $67-90$,

Saihu, S. (2019). RINTISAN PERADABAN PROFETIK UMAT MANUSIA MELALUI PERISTIWA TURUNNYA ADAM AS KE-DUNIA. Mumtaz: Jurnal Studi Al-Quran dan Keislaman, 3(2), 268-279,

Saihu, S. (2020). ETIKA MENUNTUT ILMU MENURUT KITAB TA'LIM MUTA'ALIM. Al Amin: Jurnal Kajian Ilmu dan Budaya Islam, 3(1), 99-112.

Saihu, S. (2020). KONSEP PEMBAHARUAN PENDIDIKAN ISLAM MENURUT FAZLURRAHMAN. Andragogi: Jurnal Pendidikan Islam dan Manajemen Pendidikan Islam, 2(1), 82-95.

Saihu, S. (2020). Pendidikan sosial yang terkandung dalam Surat At-Taubah Ayat 7172. Edukasi Islami: Jurnal Pendidikan Islam, 9(01), 127-148.

Saihu, S. (2020). The Effect of Using Talking Stick Learning Model on Student Learning Outcomes in Islamic Primary School of Jamiatul Khair, Ciledug Tangerang. Tarbawi: Jurnal Keilmuan Manajemen Pendidikan, 6(01), 61-68. 
Saihu, S., \& Mailana, A. (2019). Teori pendidikan behavioristik pembentukan karakter masyarakat muslim dalam tradisi Ngejot di Bali. Ta'dibuna: Jurnal Pendidikan Islam, 8(2), 163-176.

Saihu, S., \& Marsiti, M. (2019). PENDIDIKAN KARAKTER DALAM UPAYA MENANGKAL RADIKALISME DI SMA NEGERI 3 KOTA DEPOK, JAWA BARAT. Andragogi: Jurnal Pendidikan Islam dan Manajemen Pendidikan Islam, 1(1), 23-54.

Saihu, S., \& Rohman, B. (2019). PEMBENTUKAN KARAKTER MELALUI MODEL PENDIDIKAN TRANSFROMATIFE LEARNING PADA SANTRI DI PONDOK PESANTREN NURUL IKHLAS BALI. Edukasi Islami: Jurnal Pendidikan Islam, 8(02), 435-452.

Saihu, S., \& Taufik, T. (2019). PERLINDUNGAN HUKUM B AGI GURU. Al Amin: Jurnal Kajian Ilmu dan Budaya Islam, 2(2), 105-116.

Soekarno dan Ahmad Supardi, Sejarah dan Filsafat Pendidikan Islam (Bandung: Angkasa, 1983)

Syamsul Maarif, Revitalisasi Pendidikan Islam (Yogyakarta: Graha Ilmu, 2007)

Tamalene, 2011.Bahan Ajaran Pengantar Pendidikan.FKIP-Chamistry.Unkhair.Ternate 